Murat Bas

Erzincan Binali Yıldırım University

Department of Health Management

24002 Erzincan, Turkey

murat.bas@erzincan.edu.tr
Orhan Cinar

Ataturk University

Department of Labor Economics

and Industrial Relations

25030 Erzurum, Turkey

orhanar@atauni.edu.tr
JEL: $M 12$

Original scientific article

https://doi.org/10.51680/ev.34.2.4

Received: November 30, 2020

Revision received: March 8, 2021

Accepted for publishing: March 10, 2021

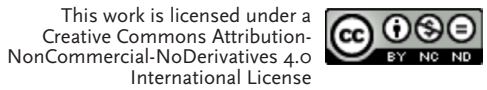

\title{
THE MEDIATING ROLE
}

OF WORK ENGAGEMENT IN

THE RELATIONSHIP BETWEEN

PERCEIVED ORGANIZATIONAL

SUPPORT AND TURNOVER

INTENTION - WITH AN APPLICATION

TO HEALTHCARE EMPLOYEES IN

ERZINCAN PROVINCE OF TURKEY ${ }^{*}$

\begin{abstract}
Purpose: The main purpose of this study is to investigate the mediating role of work engagement (WE) in the relationship between perceived organizational support (POS) and turnover intention (TI).

Methodology: In this context, to test the model and hypotheses, research data were collected using a survey method from 427 public employees working in the healthcare sector in Erzincan province of Turkey. The data were analyzed using SPSS and AMOS programs.

Results: As a result of the analyses, it was found that perceived organizational support has a positive effect on work engagement and a negative effect on turnover intention, and work engagement and turnover intention variables are negatively correlated. It was also concluded that there was a partial mediating role of work engagement in the relationship between perceived organizational support and turnover intention.

Conclusion: In this study, it was determined that WE has a partial intermediary role in the relationship between POS and TI. According to these findings, the support provided to the employee by the organization reduces employee intention to quit. In this context, when organizational management implements practices that will ensure employee commitment in addition to supporting employees and creating this perception, it can further reduce the intention of employees to quit.
\end{abstract}

Keywords: Perceived organizational support, work engagement, turnover intention, healthcare sector

This study is derived from the PhD study titled "THE MEDIATING ROLE OF WORK ENGAGEMENT IN THE RELATIONSHIP BETWEEN PERCEIVED ORGANIZATIONAL SUPPORT AND TURNOVER INTENTION - WITH AN APPLICATION ON HEALTHCARE EMPLOYEES IN ERZINCAN PROVINCE OF TURKEY" under the supervision of Prof. Dr. Orhan ÇINAR, Erzincan Binali Yıldırım University, Institute of Social Sciences. 


\section{Introduction}

Since the focus of the health sector is human life, health sector employees work in a physically, emotionally, and cognitively more difficult and stressful environment compared to other service sector employees. In this challenging environment, communication and synergy that organizations will establish with employees are important. Also, the ability of healthcare professionals to focus on the goals of the organization and to use their talents depends on their integration with the work, their sense of belonging to the organization, and their ability to personally undertake organizational success or failure. In this case, employees' perception of organizational support comes into prominence. Perceived organizational support (POS) refers to "employees' perception that the organization values their contribution and cares about their well-being" (Eisenberger et al., 2002). Studies demonstrated that employees who perceive high organizational support show higher job satisfaction (Aube et al., 2007; Krishnan \& Marry, 2012), work engagement (WE) (e.g. Saks, 2006; Rich et al., 2010; Murthy, 2017), organizational commitment (e.g. Loi et al., 2006; Arshadi, 2011) and organizational citizenship behavior (e.g., Noruzy et al., 2011; Singh \& Singh, 2013), while experiencing lower turnover intention (TI) (e.g. Rhoades \& Eisenberger, 2002; Perryer et al., 2010).

Many occupations in the health sector involve harsh conditions such as long working hours, shift work, and busy work pace. For this reason, in addition to healthcare professionals' POS, their WE levels are extremely important in terms of patient satisfaction, and ultimately organizational performance, because engaged employees perform better as they are strongly connected to and focused on their work (Schaufeli et al., 2002, p. 74) and thus contribute to achieving better financial results for the organization (Bakker \& Albrecht, 2018, p. 5). WE is also a significant attitude that provides many benefits to the organization such as higher creativity, job performance, job satisfaction, organizational citizenship behavior, customer satisfaction, and lower turnover intention (Saks, 2006; Xanthopoulou et al., 2009; Bakker \& Albrecht, 2018). Therefore, organizations working with engaged employees achieve their goals more easily. As a result, WE is essential for both organizational success and employees to enjoy their work.

Based on all this information, this study tried to find the answer to the following question: "Does
WE have a mediating role in the relationship between POS and TI?" Within this framework, in this research, the terms POS, WE and TI and the relationship between these concepts were examined in light of the literature review and hypotheses were formed. After that, the data obtained from the health sector employees through the survey method were analyzed using statistical methods and the analysis results were evaluated and discussed. Finally, suggestions were made to those concerned, sector managers, and researchers who would like to make similar research studies in the future.

\section{Conceptual framework}

\subsection{Perceived organizational support}

Organizational support theory was developed by Eisenberger et al. in 1986. They defined POS as "employees' perception that the organization values their contribution and cares about their well-being" (Eisenberger et al., 2002, p. 565). In short, organizational support theory emphasizes that employees feel and perceive themselves safe in their institutions. This emerging trust enables employees to meet their social and emotional needs by increasing their productivity and to reconcile their general beliefs with the attitudes and beliefs of the organization (Eisenberger et al., 1986). The foundation of POS is based on social change theory (Blau, 1964). The reciprocity norm of social exchange theory argues that when individuals encounter positive behaviors, they react positively to these behaviors as an obligation (Gouldner, 1960). In this framework, an employee with a high perception of organizational support feels obliged to contribute to the organization in return (Eisenberger et al., 1998).

\subsection{Work engagement}

WE was first conceptualized by Kahn and defined as "dedication of employees to their work physically, cognitively, and emotionally" (Kahn, 1990, p. 694). After Kahn, different definitions of WE were made. To illustrate, Harter et al. (2002, p. 269) define the term as "the individual's involvement and satisfaction with as well as enthusiasm for work." According to Saks (2006, p. 602), who handled WE multi-dimensionally, WE is "a distinct and unique construct that consists of cognitive, emotional, and behavioral components that are associated with individual role performance." On the other hand, in the definition made by Schaufeli et al., which is frequently cited in the literature, WE is expressed as "a positive, fulfilling, work-related state of mind that 
is characterized by vigor, dedication, and absorption" (Schaufeli et al., 2002, p. 74), whereby, "vigor is characterized by high levels of energy and mental resilience while working, the willingness to invest effort in one's work, and persistence even in the face of difficulties; dedication is characterized by a sense of significance, enthusiasm, inspiration, pride, and challenge, and absorption is characterized by being fully concentrated and deeply engrossed in one's work, whereby time passes quickly and one has difficulties with detaching oneself from work" (Schaufeli et al., 2002, pp. 74-75).

Although the terms "work engagement" and "employee engagement" are used interchangeably in the literature, work engagement is considered to be a more specific concept. While work engagement focuses on the employee-job relationship, employee engagement also includes the employee's relationship with his/her organization. However, in this case, confusion about the meaning is possible between the term work engagement and the concepts of organizational commitment and extra-role behavior (Schaufeli, 2013) ${ }^{1}$. To avoid this confusion, the term "work engagement" is used in this study.

\subsection{Turnover intention}

Turnover is the termination of business ties between the organization and the individual (Tett \& Meyer, 1993). There are two types of turnover behavior: voluntary turnover and involuntary turnover. In the case of voluntary turnover, an individual initiates the process of terminating the business relationship with the organization, while the organization starts the act of dismissing or leaving the employee in involuntary turnover (Price \& Mueller, 1981). TI occurs just before voluntary turnover and it is accepted as the strongest precursor of actual turnover behavior (Lee \& Mowday, 1987; Mowday et al., 1984; Bartlett, 1999). Therefore, to understand the reason why employees leave their jobs, it is significant to determine which factors affect their intention to leave. The term TI is defined as "a conscious and deliberate willfulness to leave the organization" (Tett \& Meyer, 1993). This intention can occur on a planned or unplanned basis and is determined by reference to a specific time frame. For example, an employee may state that he/she will quit the job at intervals such as the next month or next year. Organizations should attach importance to TI of employees due to its effect on the employee turnover rate.

1 Schaufeli, W. B. \& Bakker, A. B. (2003). UWES Utrecht Work Engagement Scale. Utrecht University (November 2003)

\section{Research hypotheses}

\subsection{The relationship between POS and TI}

Many studies were identified in the literature examining the relationship between POS and TI. For example, Rhoades and Eisenberger (2002) found a negative relationship between POS and TI. Accordingly, within the framework of the reciprocity norm, the employee who perceives organizational support firstly feels the obligation to fulfill his/her responsibilities for the organization. Then, he/she develops positive thinking and organizational commitment towards the organization (Eisenberger et al., 2002). Thus, the employee with increased organizational commitment shows less turnover intention and behavior (Rhoades et al., 2001). In addition, Perryer et al. (2010) determined in their study that the relationship between POS and organizational commitment is an important determinant of $\mathrm{TI}$, and employees with low organizational commitment are less likely to turnover if they receive high organizational support from their organization. In the study conducted by Joo et al. (2015), it was concluded that when employees perceive that the organization cares about their well-being (POS) and when they are assigned to a difficult or challenging job, they show less quitting behavior. In his research in Turkey, Yakut (2020) found a negative relationship between POS and TI. Lastly, research conducted by Islam et al. (2018), Wang \& Wang (2020), and Giao et al. (2020) affirmed that POS is negatively correlated with TI. The following hypothesis was developed in line with previous research:

H1: POS negatively and significantly affects TI.

\subsection{The relationship between POS and WE}

Various studies in the literature revealed the presence of a positive relationship between POS and WE. One of the most important studies is Saks' work. In his study examining the antecedents and consequences of WE, Saks (2006) found that one of the strongest determinants of WE is POS, and based this relationship on social exchange theory. Another significant study by Rich et al. (2010) investigated the antecedents of WE and its effects on job performance and revealed that employees who perceive high organizational support are more engaged in their jobs. Murthy (2017) also determined in his study that there was a significant and positive relationship between POS and WE. Moreover, Özdemir et al. (2019) reported in their study that POS 
has a positive effect on the sub-dimensions (vigor, dedication, and absorption) of WE. Finally, different studies conducted by Najemdeen et al. (2018), Kerse \& Karabey (2019), and Imran et al. (2020) confirmed that there is a positive correlation between POS and WE. In this context, the following hypothesis was created:

H2: POS positively and significantly affects WE.

\subsection{The relationship between WE and the TI}

Since WE is defined as a positive, fulfilling, and work-related state of mind (Schaufeli et al., 2001), engaged employees are actively and intensely dedicated to their jobs with positive energy, and do not have negative thoughts like TI (Saks, 2006, p. 609). In their study, Schaufeli \& Bakker (2004) concluded that job resources increase employees' WE and decrease their TI. Accordingly, job resources (e.g. job autonomy, performance feedback, and social support) are both internal and external motivation sources, as they encourage employees to develop and learn, and enable them to achieve their work-related goals. When employee motivation increases, they are more engaged in their work and thus think less about quitting. There are also other studies that detect a negative relationship between WE and TI (Shuck et al., 2011; Erdil \& Müceldili, 2014; Gupta \& Shaheen, 2017; De Simone et al., 2018; Lee et al., 2018; Erdirençelebi \& Karataş, 2019; Zhang et al., 2020). In this context, the following hypothesis was formed:

H3: WE negatively and significantly affects TI.

\subsection{The mediating role of WE in the relationship between POS and TI}

In addition to the direct effect of POS on TI, its indirect effect through WE was also examined in this study. In other words, within the framework of the reciprocity norm, it was thought that employees who perceive that the organization cares about their contributions and well-being will be more engaged in their jobs and thus will have less TI. There are different studies that have previously investigated this mediating effect. To illustrate, Thirapatsakun et al. (2014) found in their study that POS has an indirect effect on TI through WE. Also, Kumar et al. (2018) revealed that WE has a mediating role in the relationship between POS for employee selfdevelopment and TI. Besides, the study conducted by Nadeem et al. (2019) demonstrated that there is a negative relationship between POS and TI, a positive relationship between POS and WE, and a negative relationship between WE and TI, and that WE has a significant mediating role in the relationship between POS and TI. In their study, Putra and Surya (2019, p. 19) determined that POS has a significant negative effect on TI and a significant positive effect on WE; furthermore, WE has a significant negative effect on TI and a partial mediating role in the relationship between POS and TI. Accordingly, the following hypothesis was developed:

H4: WE has a mediating role in the relationship between POS and TI.

The research model created based on the hypotheses is given in Figure 1.

\section{Figure 1 Research model}

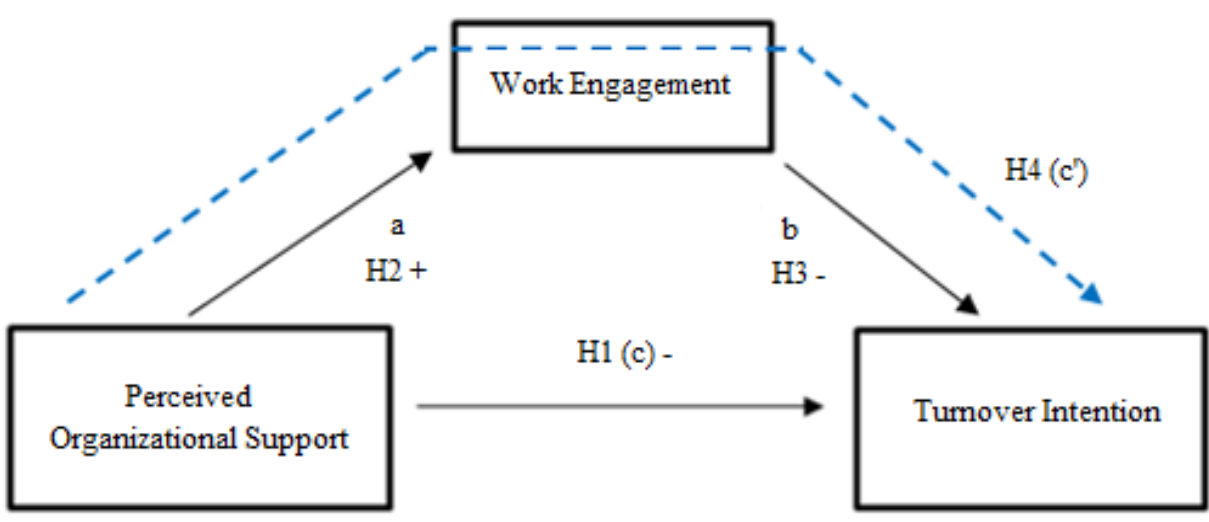

Source: Authors 


\section{Method}

\subsection{The aim and importance of research}

Various studies have examined the relationship between POS and TI (Mathumbu \& Dodd, 2013; Burns, 2016; Araya, 2015; Christianson, 2015; Bano et al., 2015; Caesens \& Stinglhamber, 2014; Murthy, 2017). Some researchers handling this relationship suggested that future studies could include different variables in the model. In line with this suggestion, this study tried to reveal the mediating role of WE in the relationship between POS and TI. On the other hand, it has been determined that previous studies have investigated this mediating role $(\mathrm{Na}-$ deem et al, 2019; Putra \& Surya, 2019; Kumar et al., 2018; Thirapatsakun et al., 2014).

\subsection{Research universe and sample}

The research universe was composed of 1,300 healthcare professionals working in Erzincan province of Turkey. Accordingly, the sample size was determined as 281 by predicting $95 \%$ reliability and $5 \%$ error margin for the universe size ${ }^{2}$. In this context, 450 questionnaires were distributed to the employees by using a simple random sampling method, and 427 complete and error-free questionnaires were analyzed. The data collection process in this research took 8 months.

\subsection{Data collection and analysis}

\subsubsection{Data collection tools}

The research questionnaire consists of two parts. The first part includes questions to determine the demographic characteristics of the survey participants. In the second part, there are questions about POS, WE and TI. The scales used in the study are explained below:

POS Scale: A 36-item POS scale developed by Eisenberger et al. (1986) was shortened by Armstrong-Stassen \& Ursel (2009), and a 10-item validation study was conducted. Akkoç et al. (2012) adapted this abbreviated version to Turkish needs by removing two items (6 and 9) due to their low factor values. For this reason, an 8-item scale adapted by Akkoç et al. (2012) was used in this study.

WE Scale: Participants' WE was measured by using a 9-item scale developed by Schaufeli \& Bakker (2003) and adapted to Turkish needs by Özkalp \& Meydan (2015).

2 Sample Size Calculator. http://www.surveysystem.com/sscalc.htm
TI Scale: The scale developed by Rosin and Korabik (1995) and adapted to Turkish needs by Tanriöver (2005) was used to measure participants' TI. The scale consists of one dimension and 4 items in total.

Research questions were answered with a 5-point Likert-type scale (1-strongly disagree, 5-strongly agree). To determine the methods to be used in the analysis, the normality test was performed first. However, as a result of the normality test, it was determined that the data were not distributed normally, so non-parametric tests were used in data analysis. Reliability analysis, factor analysis, Spearman correlation analysis, SEM analysis, and mediator variable analysis were also applied in the study. The data obtained were analyzed through AMOS 17 and SPSS 22 software packages.

\section{Results}

\subsection{Demographic findings}

When the demographic characteristics of the participants are examined, $53.9 \%$ of the participants are female, $46.1 \%$ are male; $74 \%$ are married, $26 \%$ are single; $15.4 \%$ are in the $20-25$ age range, $40.1 \%$ are in the $26-40$ age range, and $44.5 \%$ are in the 41 and over age range. In terms of education, $32.3 \%$ of the respondents are high school graduates, $31.1 \%$ are associate degree graduates and $36.6 \%$ are undergraduate graduates. On the other hand, $8.7 \%$ of the participants are doctors, $34.4 \%$ nurses, $16.9 \%$ health officers, and $40 \%$ other healthcare professionals. With regards to the working time of the participants, those working 11 years, or more are in the majority (45.4\%), there are $29.3 \%$ of those working 1-5 years, and $25.3 \%$ of those with 6-10 years of work experience.

\subsection{Reliability and factor analysis results regarding the scales}

Exploratory factor analysis results and reliability coefficients for the scales are given in Table 1. It can be seen from the table that the Cronbach Alpha coefficient of POS is above the reference value of $0.70(0.945)$. The scale explains $72.431 \%$ of the total variance. The KMO value for the scale is 0.919 and the sphericity value is 0.000 . These values meet the referenced values $(\mathrm{KMO}>0.60$ and sphericity value $<0.05$ ). In addition, the Cronbach Alpha coefficient of the WE scale is above the reference $0.70(0.874)$. The scale explains $52.775 \%$ of the total variance. The KMO value for the scale is 0.853 and 
the sphericity value is 0.000 . These values meet the referenced values $(\mathrm{KMO}>0.60$ and sphericity value $<0.05)$. Finally, the Cronbach Alpha coefficient of the TI scale is above the reference $0.70(0.884)$. The scale explains $74.415 \%$ of the total variance. The $\mathrm{KMO}$ value for the scale is 0.794 and the sphericity value is 0.000 . These values meet the referenced values $(\mathrm{KMO}>0.60$ and sphericity value $<0.05)$.

Table 1 Exploratory factor analysis results regarding the research scales

\begin{tabular}{|c|c|c|c|c|c|}
\hline SCALE & 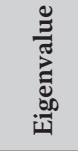 & 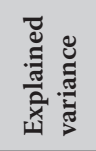 & 丞 & 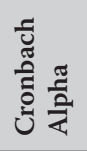 & \\
\hline POS & 5.794 & 72.431 & 72.431 & 0.945 & $\begin{array}{l}\qquad \mathrm{KMO}=.919 \\
\text { Bartlett's test of sphericity }(\text { statistical value }=3094,542 ; \mathrm{p}=.000)\end{array}$ \\
\hline WE & 4.750 & 52.775 & 52.775 & 0,874 & $\begin{array}{l}\qquad \mathrm{KMO}=.853 \\
\text { Bartlett's test of sphericity }(\text { statistical value }=2319,537 ; \mathrm{p}=.000)\end{array}$ \\
\hline TI & 2.977 & 74.415 & 74.415 & 0.884 & $\begin{array}{l}\qquad \mathrm{KMO}=.794 \\
\text { Bartlett's test of sphericity }(\text { statistical value }=974,142 ; \mathrm{p}=.000)\end{array}$ \\
\hline
\end{tabular}

Source: Authors

Confirmatory factor analysis was applied to the variables after exploratory factor analysis. The results are given in Table 2.

Table 2 Goodness of fit after modification for the variables

\begin{tabular}{|l|c|c|c|c|c|c|}
\hline & X2/df & RMSEA & CFI & GFI & NFI & TLI \\
\hline POS & 2.764 & 0.064 & 0.992 & 0.978 & 0.988 & 0.984 \\
\hline WE & 3.294 & 0.073 & 0.990 & 0.981 & 0.985 & 0.976 \\
\hline TI & 0.028 & 0.000 & 1.000 & 1.000 & 1.000 & 1.000 \\
\hline
\end{tabular}

Source: Authors

The goodness of fit values in the table show that the reference values are provided, so the modifications improve the model fit. Therefore, the factor structure obtained by exploratory factor analysis is confirmed.

\subsection{Findings regarding hypothesis test results}

a) Correlation analysis

Relationships between the research variables were determined through correlation analysis. Since the data were not normally distributed, Spearman correlation analysis was preferred (Field, 2009). In this context, the obtained findings are given in Table 3.

Table 3 Correlation analysis (Spearman's rho) findings

\begin{tabular}{|c|c|c|c|c|c|c|}
\hline Factors & $\mathbf{X}$ & SS & & 1 & 2 & 3 \\
\hline \multirow{2}{*}{ 1-POS } & \multirow{2}{*}{2.742} & \multirow{2}{*}{1.101} & Spearman's & 1 & $.403^{* * *}$ & $-.303 \%$ \\
\hline & & & $\mathrm{P}$ & & 0.000 & 0.000 \\
\hline \multirow{2}{*}{$2-W E$} & \multirow{2}{*}{3.330} & \multirow{2}{*}{1.008} & Spearman's & & 1 & $-.383^{* * \%}$ \\
\hline & & & $\mathrm{P}$ & & & 0.000 \\
\hline \multirow{2}{*}{ 3-TI } & \multirow{2}{*}{2.354} & \multirow{2}{*}{1.180} & Spearman's & & & 1 \\
\hline & & & $\mathrm{p}$ & & & \\
\hline
\end{tabular}

* If $\mathrm{p}<0.05$, there is a $95 \%$ significance level relationship between the variables.

** If $\mathrm{p}<0.001$, there is a $99 \%$ significance level relationship between the variables.

Source: Authors 
As can be seen in Table 4, there is a negative correlation between POS and TI at the 99\% significance level $(\mathrm{r}=-0.303 ; \mathrm{p}=0.000)$. According to this finding, an increase in the POS levels of employees decreases their TI levels. However, employees with a low perception of organizational support may intend to quit more.

There is also a positive correlation $(\mathrm{r}=0.403$; $\mathrm{p}=$ 0.000 ) between POS and WE at the $99 \%$ significance level. This finding means that when employees have a perception that they receive support from the organization, they are more engaged in their work; on the other hand, when employees think that they do not receive support from the organization, their work engagement levels decrease.

Another finding in the table is that there is a negative correlation $(\mathrm{r}=-0.383 ; \mathrm{p}=0.000)$ between WE and TI at the $99 \%$ significance level. Accordingly, engaged employees tend to turnover less. Conversely, employees with low levels of engagement may intend to quit more.

\section{b) Structural equation modeling analysis}

In the research, a structural equation model was applied to the variables with the AMOS program. However, it should be determined whether there is a multicollinearity problem as a prerequisite of the analysis. For this reason, multicollinearity of the independent variables was examined first. The multicollinearity problem occurs when the variance inflation factor (VIF) of the independent variables is above 10 and the tolerance indices (the variance ratio that cannot be explained by the variables) are below 0.10 (Kerse \& Karabey, 2019). As a result of the analysis, it was concluded that there is no multicollinearity problem since the VIF values of the independent variables POS and TI are below 10 and the tolerance indices are above 0.10 (Table 4).

Table 4 Multicollinearity regarding independent variables

\begin{tabular}{|c|c|c|}
\hline Independent variables & Tolerance & VIF \\
\hline POS & .838 & 1.193 \\
\hline WE & .838 & 1.193 \\
\hline
\end{tabular}

Source: Authors

As stated above, structural equation modeling analysis was performed to test the hypotheses. In structural equation modeling, POS, TI and WE were determined as the exogenous variable, the dependent variable (endogenous variable) and the mediator variable, respectively.

On the other hand, since the data were not distributed normally, the bootstrap method was used (Bayram, 2013, p. 106), while the sample and the bias-corrected confidence intervals were kept at 1000 and at 95\%, respectively. Analyses were made by selecting the boost factor value as 1 . The model estimation results are shown in Figure 2.

\section{Figure 2 Research model estimation results}

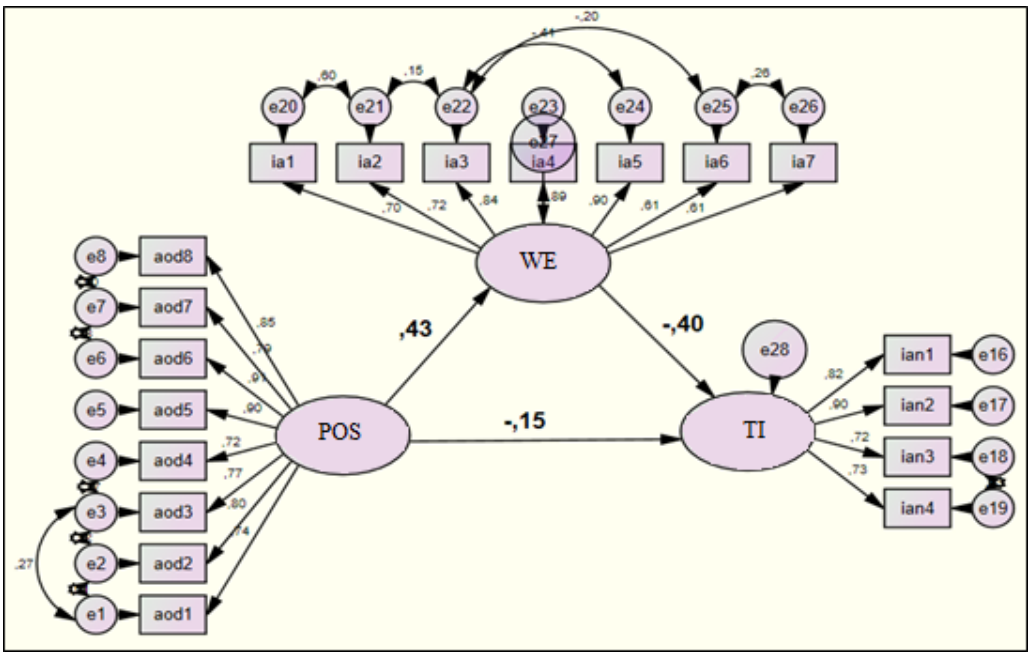

Source: Authors 
The goodness of fit values for the research model are shown in Table 5. It can be seen in the table that the reference values are met.

Table 5 Goodness of fit values of the research model

\begin{tabular}{|l|l|c|c|}
\hline \multicolumn{1}{|c|}{ Indices } & Meaning & Reference value & $\begin{array}{c}\text { Measurement } \\
\text { model }\end{array}$ \\
\hline CMIN/DF & Chi Square / Degrees of Freedom & $0<x^{2} / \mathrm{sd} \leq 5$ & 1.607 \\
\hline CFI & Comparative Goodness of Fit Index & $>.90$ & .987 \\
\hline RMR & Rock Mass Rating & $<.1$ & .061 \\
\hline GFI & Goodness of Fit Index & $>.90$ & .949 \\
\hline IFI & Incremental Fit Index & $>.90$ & .987 \\
\hline TLI & Tucker-Lewis Index & $>.90$ & .984 \\
\hline NFI & Normed Fit Index & $>.90$ & .966 \\
\hline RMSEA & Root Mean Square Error of Approximation & $<.05$ RMSEA .08 & .038 \\
\hline
\end{tabular}

Source: Authors

The standardized factor loadings and bootstrap confidence intervals obtained in the basic model are summarized in Table 6. According to these values:

1- The effect of POS on TI is statistically significant at the $95 \%$ significance level,

2- The effect of POS on WE is statistically significant at the $99 \%$ significance level,
3- The effect of WE on TI is statistically significant at the $99 \%$ significance level.

The lower-level and upper-level values in the table demonstrate the intervals in which the independent variable affects the dependent variable.

Table 6 Factor loadings and bootstrap confidence intervals

\begin{tabular}{|c|c|c|c|c|c|c|c|}
\hline Hypothesis & $\begin{array}{c}\text { Dependent } \\
\text { variable }\end{array}$ & & $\begin{array}{c}\text { Independent } \\
\text { variable }\end{array}$ & $\begin{array}{c}\text { Standardized } \\
\text { factor } \mathbf{l} .\end{array}$ & $\begin{array}{c}\text { Lower } \\
\text { level }\end{array}$ & $\begin{array}{c}\text { Upper } \\
\text { level }\end{array}$ & P \\
\hline H1 & TI & $\leftarrow$ & POS & -.15 & -.254 & -.053 & $.012 \%$ \\
\hline H2 & WE & $\leftarrow$ & POS & .43 & .339 & .509 & $.007 \%$ \\
\hline H3 & TI & $\leftarrow$ & WE & -.40 & -.485 & -.297 & $.008 \%$ \\
\hline
\end{tabular}

** If $\mathrm{p}<0.01$, the effect between variables is statistically significant at the $99 \%$ significance level.

*If $\mathrm{p}<0.05$, the effect between variables is statistically significant at the $95 \%$ significance level.

Source: Authors

Direct, indirect and total effects in the basic research model obtained by means of the bootstrap method are summarized in Table 7.

Table 7 Direct, indirect and total effects in the basic research model

\begin{tabular}{|c|c|c|c|c|}
\hline Variables & Effects & POS & WE & TI \\
\hline \multirow{3}{*}{ WE } & Direct & $\mathbf{. 4 3}$ & .000 & .000 \\
\cline { 2 - 5 } & Indirect & .000 & .000 & .000 \\
\cline { 2 - 5 } & Total & $\mathbf{. 4 3}$ & .000 & .000 \\
\hline \multirow{3}{*}{ TI } & Direct & $\mathbf{- . 1 5}$ & $\mathbf{- . 4 0}$ & .000 \\
\cline { 2 - 5 } & Indirect & $\mathbf{- . 1 7}$ & .000 & .000 \\
\cline { 2 - 5 } & Total & $\mathbf{- . 3 2}$ & $\mathbf{- . 4 0}$ & .000 \\
\hline
\end{tabular}

Source: Authors 


\section{Hypothesis 1: POS negatively and significantly affects TI.}

Values showing the relationship between POS and TI are given in Table 4, Table 7, and Table 8. The findings show that there is a negative correlation between POS and TI at the 99\% significance level (Table 4; $\mathrm{r}=-0.303 ; \mathrm{p}=0.000$ ) and that POS affects TI directly, significantly and negatively at the 95\% significance level (Table 7; Standardized R.Y. $=-0.15 ; \mathrm{p}=0.012)$. Furthermore, the total effect of POS on TI is -0.32 (Table 8). This means that an increase in the POS levels of employees decreases their TI levels. Hence, the H1 hypothesis was accepted. This finding is in line with the results of previous studies (Galletta et al., 2011; Koster et al., 2011; Park et al., 2015; Joo et al., 2015).

\section{Hypothesis 2: POS positively and significantly affects WE.}

Values referring to the relationship between POS and WE are shown in Table 4, Table 7, and Table 8. Accordingly, there is a positive correlation between POS and WE at the 99\% significance level (Table $4 ; \mathrm{r}=-0.403 ; \mathrm{p}=0.000$ ) and POS impacts WE at the $99 \%$ significance level directly, significantly and positively (Table 7; Standardized R.Y. $=0.43 ; \mathrm{p}=$ 0.007). The total effect of POS on WE is 0.43 (Table $8)$. That is, when employees have the perception that they receive support from the organization, they are more engaged at work or vice versa. Therefore, the $\mathrm{H} 2$ hypothesis was accepted. This finding confirms the previous studies (Saks, 2006; Rich et al., 2010; Zacher \& Winter, 2011; Biswas et al., 2013; Gillet et al., 2013; Caesens \& Stinglhamber, 2014) that established a positive relationship between POS and WE.

\section{Hypothesis 3: WE negatively and significantly affects TI.}

Values showing the relationship between WE and TI are given in Table 4, Table 7, and Table 8. According to the findings, there is a negative correlation between WE and TI at the 99\% significance level (Table 4; $\mathrm{r}=-0.383 ; \mathrm{p}=0.000$ ) and WE affects $\mathrm{TI}$ at the 99\% significance level directly, significantly and negatively (Table 7; Standardized R.Y. = - 0.40; p = 0.008). Furthermore, the total effect of POS on TI is -0.40 (Table 8). Accordingly, it can be said that employees with increased levels of work engagement are less likely to involve in turnover in- tentions. Therefore, the H3 hypothesis was accepted. This result coincides with the results of previous studies (Schaufeli et al., 2001; Schaufeli \& Bakker, 2004; Saks, 2006; Koyuncu et al., 2006; Shuck et al., 2011; Agarwal et al., 2012; Erdil \& Müceldili, 2014).

\section{Hypothesis 4: WE has a mediating role in the re-} lationship between POS and TI.

The conditions suggested by Baron and Kenny (1986) were used to reveal the mediating role of WE in the relationship between POS and TI. These conditions are as follows:

1. The independent variable (POS) must affect the dependent variable (TI). The H1 hypothesis satisfies this requirement (Figure 3, Direct Effect $=-0.150$ )

2. The independent variable (POS) must affect the mediator variable (WE). The $\mathrm{H} 2$ hypothesis fulfills this requirement (Figure 3, Direct Effect $=0.430$ ).

3. The mediator variable (WE) must affect the dependent variable (TI). The $\mathrm{H} 3$ hypothesis fulfills this requirement (Figure 3, Direct Effect $=-0.400)$.

4. When the mediator variable is included in the analysis, a statistical decrease in the effect of the independent variable on the dependent variable indicates that there is a partial mediating role. The fact that the relationship between the dependent and the independent variable becomes statistically insignificant specifies that there is a perfect mediating role (Baron \& Kenny, 1986).

In the model without the mediating variable, POS (an independent variable) affects TI (a dependent variable) at the level of -0.320 . When WE (a mediating variable) is included in the model, the impact of POS on TI decreases and becomes -0.150. This can be explained by the fact that WE plays a partial mediating role in the relationship between POS and TI. According to the values in Table 8 , the direct effect of POS on TI is -0.150 , the indirect effect is -0.170 and the total effect is -0.320 . It can be said that this indirect effect is caused by the "WE" variable. That is, WE has a partial mediating role in the relationship between POS and TI (Figure 3). Therefore, the H4 hypothesis was accepted. 
Figure 3 Partial mediating role of WE in the relationship between POS and TI
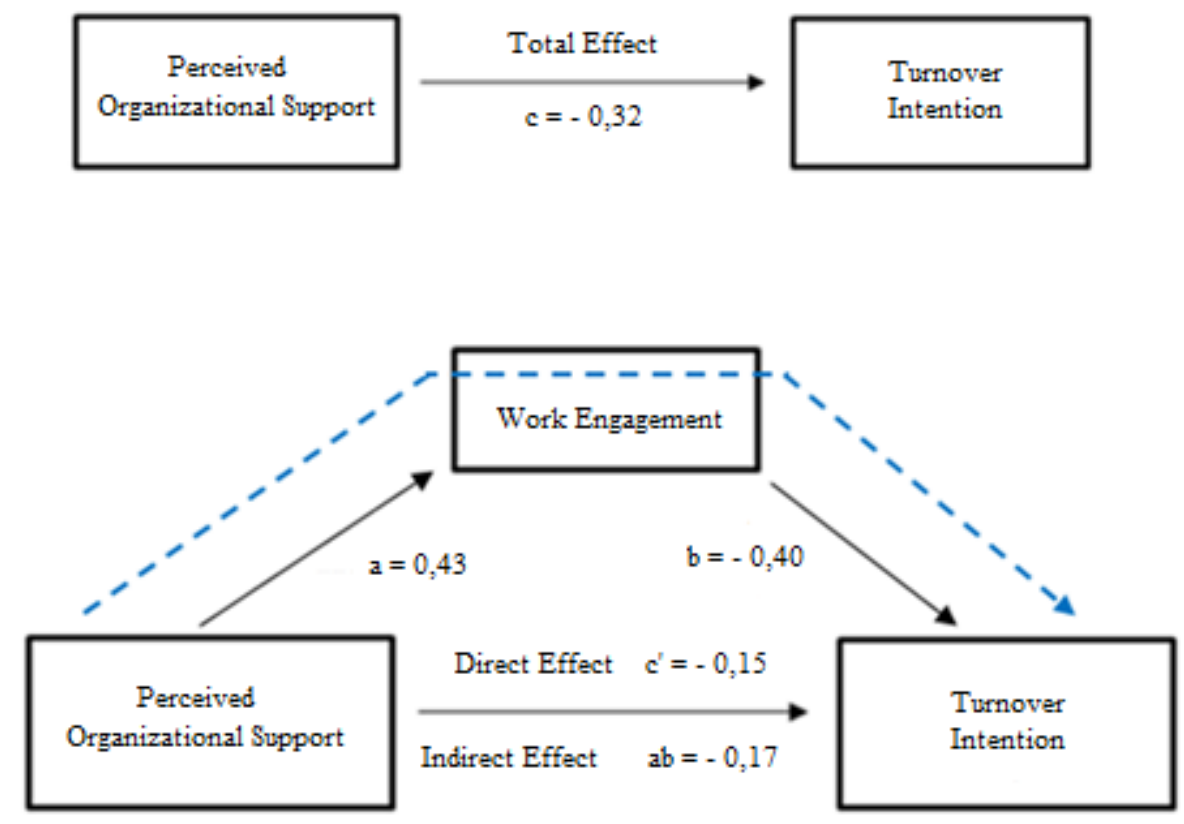

Source: Authors

\section{Discussion}

Relationships between the POS, WE, and TI variables, as well as the mediating role of WE in the relationship between POS and TI were examined in this study. As a result of the analysis, it was seen that all hypotheses were supported. First of all, this study revealed a negative and significant relationship between POS and TI (H1). In other words, it was found that organizational support practices, such as thinking about their employee well-being and welfare, rewarding their good performance, valuing their ideas and opinions, listening to their problems, and trying to find solutions, are effective in employee turnover behavior. Secondly, this study determined that there is a positive and significant relationship between POS and WE (H2). Within this scope, employees who perceive a high level of organizational support tend to be more engaged at work. Thirdly, this study found a negative and significant relationship between WE and TI (H3). That is, employees who are dedicated to their jobs physically, cognitively, and emotionally are less likely to think about quitting these jobs.
Lastly, this study revealed that there is a partial mediating role of WE in the relationship between POS and TI (H4). In other words, employees who perceive that the organization cares about their contributions and well-being will be more engaged in their jobs and thus will have less TI. In this framework, when supervisors implement practices that ensure employee engagement in addition to providing organizational support to them, they can further reduce their TI. These practices may include enabling employees to take initiative in their jobs, following better wages policy, treating employees fairly and transparently, enabling employees to develop their skills through career planning, ensuring their participation in symposiums, congresses, or seminars related to their job, communicating and interacting with employees according to their personalities and giving importance to their health, etc.

\section{Conclusion}

This study examined relationships between the POS, WE, and TI variables, as well as the mediating role of WE in the relationship between POS and TI. The findings of this study provide evidence that em- 
ployees' perceptions of organizational support and work engagement are effective in relation to their turnover intention. Furthermore, the results demonstrate that employees with perceived organizational support are more engaged in their work and thus less likely to quit their jobs. Therefore, in order to prevent employee turnover, organizations should not only implement organizational support policies but also ensure employee engagement.

\section{Limitations}

As in all studies, this study has some limitations. For example, due to cost and accessibility reasons, it covers only one industry and includes data for a single city. Future studies may expand the sample size by including employees from different sectors and different professions. Besides, future studies may compare health institutions in various regions or cities.

The mediating role of WE in the relationship between POS and TI was examined in this study. In future studies, new models can be established and tested with different mediating variables (e.g. organizational justice, leader-member exchange, employee jealousy, organizational trust, and organizational commitment) that will affect the relationship between these two variables. 


\section{REFERENCES}

1. Agarwal, U. A., Datta, S., Blake-Beard, S. \& Bhargava, S. (2012). Linking LMX, innovative work behaviour and turnover intentions. Career Development International, 17(3), 208-230. https://doi.org/10.1108/13620431211241063

2. Akkoç, İ., Çalişkan, A. \& Turunç, Ö. (2012). Örgütlerde gelişim kültürü ve algılanan örgütsel desteğin iş tatmini ve iş performansına etkisi: Güvenin aracılık rolü. Yönetim ve Ekonomi: Celal Bayar Üniversitesi İktisadi ve İdari Bilimler Fakültesi Dergisi, 19(1), 105-135.

3. Araya, M. A. (2015). The interactive effect of core self-evaluations and perceived organizational support in predicting work engagement [Master's thesis, San Jose State University]. San Jose State University.

4. Armstrong-Stassen, M. \& Ursel, N. D. (2009). Perceived organizational support, career satisfaction, and the retention of older workers. Journal of Occupational and Organizational Psychology, 82(1), 201-220. https://doi.org/10.1348/096317908X288838

5. Arshadi, N. (2011). The relationships of perceived organizational support (POS) with organizational commitment, in-role performance, and turnover intention: Mediating role of felt obligation. ProcediaSocial and Behavioral Sciences, 30(1), 103-1108. https://doi.org/10.1016/j.sbspro.2011.10.215

6. Aube, C., Rousseau, V. \& Morin, E. M. (2007). Perceived organizational support and organizational commitment: The moderating effect of locus of control and work autonomy. Journal of Managerial Psychology, 22(5), 479-495. https://doi.org/10.1108/02683940710757209

7. Bakker, A. B. \& Albrecht, S. (2018). Work engagement: Current trends. Career Development International, 23(1), 4-11. https://doi.org/10.1108/CDI-11-2017-0207

8. Bano, S., Vyas, K. \& Gupta, R., (2015). Perceived organisational support and work engagement: a cross generational study. Journal of Psychosocial Research, 10(2), 357-364.

9. Baron, R. M. \& Kenny, D. A. (1986). The Moderator-Mediator Variable Distinction in Social Psychological Research: Conceptual, Strategic, and Statistical Considerations. Journal of Personality and Social Psychology, 51(6), 1173-1182. https://doi.org/10.1037/0022-3514.51.6.1173

10. Bartlett, K. R. (1999). The relationship between training and organizational commitment in the health care field. [Doctoral dissertation, University of Illinois at Urbana-Champaign]. University of Illinois at Urbana-Champaign.

11. Bayram, N. (2013). Yapısal Eşitlik Modellemesine Giriş: Amos Lygulamaları. Bursa: Ezgi Kitabevi.

12. Blau, P. (1964). Exchange and Power in Social Life. Wiley.

13. Biswas, S., Varma, A. \& Ramaswami, A. (2013). Linking distributive and procedural justice to employee engagement through social exchange: A field study in India. The International Journal of Human Resource Management, 24(8), 1570-1587. https://doi.org/10.1080/09585192.2012.725072

14. Burns, K. L. (2016). Perceived organizational support and perceived supervisor support as antecedents of work engagement [Master's thesis, San Jose State University]. San Jose State University.

15. Caesens, G. \& Stinglhamber, F. (2014). The relationship between perceived organizational support and work engagement: The role of self-efficacy and its outcomes. Revue Européenne de Psychologie Appliquée / European Review of Applied Psychology, 64(5), 259-267.

https://doi.org/10.1016/j.erap.2014.08.002

16. Christianson, M. M. (2015). Bystander effect of workplace bullying, perceived organizational support, and work engagement [Doctoral dissertation, Walden University]. Walden University.

17. De Simone, S. \& Planta, A., Cicotto, G. (2018). The role of job satisfaction, work engagement, selfefficacy and agentic capacities on nurses' turnover intention and patient satisfaction. Applied Nursing Research, 39, 130-140. https://doi.org/10.1016/j.apnr.2017.11.004

18. Eisenberger, R., Huntington, R., Hutchison, S. \& Sowa, D. (1986). Perceived organizational support. Journal of Applied Psychology, 71(3), 500-507. https://doi.org/10.1037/0021-9010.71.3.500 
19. Eisenberger, R., Armeli, S., Fasolo, P. \& Lynch, P. (1998). Perceived organizational support and police performance: The moderating influence of socioemotional needs. Journal of Applied Psychology, 83(2), 288-297. https://doi.org/10.1037/0021-9010.83.2.288

20. Eisenberger, R., Stinglhamber, F., Vandenberghe, C., Sucharski, I. L. \& Rhoades, L. (2002). Perceived supervisor support: Contributions to perceived organizational support and employee retention. Journal of Applied Psychology, 87(3), 565-573. https://doi.org/10.1037/0021-9010.87.3.565

21. Erdil, O. \& Müceldili, B. (2014). The effects of envy on job engagement and turnover intention. Procedia-Social and Behavioral Sciences, 150, 447-454. https://doi.org/10.1016/j.sbspro.2014.09.050

22. Erdirençelebi, M. \& Karataş, C. G. (2019). Örgütsel Adaletin İșe Adanmışlık İle İșten Ayrılma Niyeti Üzerine Etkisi. Business \& Management Studies: An International Journal, 7(4), 1825-1849. https://doi.org/10.15295/bmij.v7i4.1225

23. Field, A. (2009). Discovering Statistics Using SPSS. SAGE Publications.

24. Galletta, M., Portoghese, I., Penna, M. P., Battistelli, A. \& Saiani, L. (2011). Turnover intention among Italian nurses: The moderating roles of supervisor support and organizational support. Nursing $\mathcal{E}$ Health Sciences, (13)2, 184-191. https://doi.org/10.1111/j.1442-2018.2011.00596.x

25. Giao, H. N. K., Vuong, B. N.; Huan, D. D. Tushar, H. \& Quan, T. N. (2020). The effect of emotional intelligence on turnover intention and the moderating role of perceived organizational support: Evidence from the banking industry of Vietnam. Sustainability, 12(5), 1-25. https://doi.org/10.3390/su12051857

26. Gillet, N., Huart, I., Colombat, P. \& Fouquereau, E. (2013). Perceived organizational support, motivation, and engagement among police officers. Professional Psychology: Research and Practice, 44(1), 46-55. https://doi.org/10.1037/a0030066

27. Gouldner, A. W. (1960). The Norm of Reciprocity: A Preliminary Statement. American Sociological Review, 25(2), 161-178. https://doi.org/10.2307/2092623

28. Gupta, M. \& Shaheen, M. (2017). Impact of work engagement on turnover intention: Moderation by psychological capital in India. Business: Theory and Practice, 18, 136-143.

https://doi.org/10.3846/btp.2017.014

29. Harter, J. K., Schmidt, F. L. \& Hayes, T. L. (2002). Business-unit-level relationship between employee satisfaction, employee engagement, and business outcomes: A meta-analysis. Journal of Applied Psychology, 87(2), 268-279. https://doi.org/10.1037/0021-9010.87.2.268

30. Imran, M. Y., Elahi, N. S., Abid, G. \& Ashfaq, F. (2020). Impact of perceived organizational support on work engagement: Mediating mechanism of thriving and flourishing. Journal of Open Innovation: Technology, Market and Complexity, 6(82), 1-18. https://doi.org/10.3390/joitmc6030082

31. Islam, T., Ali, G. \& Ahmed, I. (2018). Protecting healthcare through organizational support to reduce turnover intention. International Journal of Human Rights in Healthcare, 11(1), 4-12.

https://doi.org/10.1108/IJHRH-03-2017-0012

32. Joo, B-K., Hahn, H-J. \& Peterson, S. L. (2015). Turnover intention: The effects of core self-evaluations, proactive personality, perceived organizational support, developmental feedback, and job complexity. Human Resource Development International, 18(2), 116-130.

https://doi.org/10.1080/13678868.2015.1026549

33. Kahn, W. A. (1990). Psychological conditions of personal engagement and disengagement at work. Academy of Management Journal, 33(4), 692-724. https://doi.org/10.5465/256287

34. Kerse, G. \& Karabey, C. N. (2019). Örgütsel sinizm ve özdeşleşme bağlamında algılanan örgütsel desteğin işe bağlanma ve politik davranış algısına etkisi. Eskişehir Osmangazi Üniversitesi İIBF Dergisi, 14(1), 83-108. https://doi.org/10.17153/oguiibf.439835

35. Koster, F., De Grip, A. \& Fouarge, D. (2011). Does perceived support in employee development affect personnel turnover?. The International Journal of Human Resource Management, 22(11), 2403-2418. https://doi.org/10.1080/09585192.2011.584404 
36. Koyuncu, M., Burke, R. J. \& Fiksenbaum, L. (2006). Work engagement among women managers and professionals in a Turkish bank. Equal Opportunities International, 25(4), 299-310. https://doi.org/10.1108/02610150610706276

37. Krishnan, J. \& Mary, V. S. (2012). Perceived organisational support - An overview on its antecedents and consequences. International Journal of Multidisciplinary Research, 2(4), 1-13.

38. Kumar, M., Jauhari, H., Rastogi, A. \& Sivakumar, S. (2018). Managerial support for development and turnover intention: Roles of organizational support, work engagement and job satisfaction. Journal of Organizational Change Management, Vol. 31(1), 135-153.

https://doi.org/10.1108/JOCM-06-2017-0232

39. Lee, T. W. \& Mowday, R. T. (1987). Voluntarily Leaving an Organization: An Empirical Investigation of Steers and Mowday's Model of Turnover. Academy of Management Journal, 30(4), 721-743. https://doi.org/10.5465/256157

40. Lee, M. C. C., Idris, M. A. \& Tuckey, M. (2018). Supervisory coaching and performance feedback as mediators of the relationships between leadership styles, work engagement, and turnover intention. Human Resource Development International, 1-26. https://doi.org/10.1080/13678868.2018.1530170

41. Loi, R., Hang-Yue, N. \& Foley, S. (2006). Linking employees' justice perceptions to organizational commitment and intention to leave: The mediating role of perceived organizational support. Journal of Occupational and Organizational Psychology, 79(1), 101-120. https://doi.org/10.1348/096317905X39657

42. Mathumbu, D. \& Dodd, N. (2013). Perceived organizational support, work engagement and organisational citizenship behaviour of nurses at Victoria Hospital. Journal of Psychology, 4(2), 87-93. https://doi.org/10.1080/09764224.2013.11885497

43. Mowday, R. T., Koberg, C. S. \& McArthur, A. W. (1984). The Psychology of the Withdrawal Process: A Cross-Validation Test of Mobley's Intermediate Linkages Model of Turnover in Two Samples. Academy of Management Journal, 27, 79-94. https://doi.org/10.5465/255958

44. Murthy, R. K. (2017). Perceived organizational support and work engagement. International Journal of Applied Research, 3(5), 738-740.

45. Nadeem K., Khan, M. A., Imtiaz, N. \& Iftikhar Y. (2019). Turnover Intention and Perceived Organizational Support; Mediating Role of Work Engagement and Organizational Commitment. European Scientific Journal, 15(10), 222-236. https://doi.org/10.19044/esj.2019.v15n10p222

46. Najemdeen, I. S., Abidemi, B. T., Rahmat, F. D. \& Bulus, B. D. (2018). Perceived organizational culture and perceived organizational support on work engagement. Academic Journal of Economic Studies, 4(3), 199-208.

47. Noruzy, A., Shatery, K., Rezazadeh, A. \& Hatami-Shirkouhi, L. (2011). Investigation the relationship between organizational justice and organizational citizenship behavior: The mediating role of perceived organizational support. Indian Journal of Science and Technology, 4(7), 842-847. https://doi.org/10.17485/ijst/2011/v4i7.21

48. Özdemir, B., Özcan, H. M. \& Yalçinkaya, A. (2019). Algılanan Örgütsel Destek Ve Çalışmaya Tutkunluk Arasındaki Ilişkide Örgütsel Güvenin Aracı Rolü: Akademisyenler Üzerine Bir Araştırma. Bilecik Şeyh Edebali Üniversitesi Sosyal Bilimler Enstitüsü Dergisi, 4(2), 706-724. https://doi.org/10.33905/bseusbed.640815

49. Özkalp, E. \& Meydan, B. (2015). Schaufeli ve Bakker tarafından geliştirilmiş olan işe angajeolma ölçeğinin Türkçede güvenilirlik ve geçerliliğinin analizi. İŞ-GÜÇ: Endüstri İlişkileri ve İnsan Kaynakları Dergisi, 17(3), 4-19. https://doi.org/10.4026/1303-2860.2015.0285.x

50. Park, J. H., Newman, A., Zhang, L., Wu, C. \& Hooke, A. (2015). Mentoring functions and turnover intention: The mediating role of perceived organizational support. The International Journal of Human Resource Management, 27(11), 1173-1191. https://doi.org/10.1080/09585192.2015.1062038

51. Perryer, C., Jordan, C., Firns, I. \& Travaglione, A. (2010). Predicting turnover intentions. Management Research Review, 33(9), 911-923. https://doi.org/10.1108/01409171011070323 
52. Price, J. L. \& Mueller, C. W. (1981). A Causal Model of Turnover for Nurses. Academy of Management Journal, 24(3), 543-565. https://doi.org/10.5465/255574

53. Putra, P. D. S. S. \& Surya, I. B. K. (2019). The effect of perceived organizational support on work engagement and turnover intention. International Journal of Education and Social Science Research, 2(4), 19-33.

54. Rhoades, L., Eisenberger, R. \& Armeli, S. (2001). Affective commitment to the organization: The contribution of perceived organizational support. Journal of Applied Psychology, 86(5), 825-836. https://doi.org/10.1037/0021-9010.86.5.825

55. Rhoades, L. \& Eisenberger, R. (2002). Perceived organizational support: A review of the literature. Journal of Applied Psychology, 87(4), 698-714. https://doi.org/10.1037/0021-9010.87.4.698

56. Rich, B. L., Lepine, J. A. \& Crawford, E. R. (2010). Job engagement: Antecedents and effects on job performance. Academy of Management Journal, 53(3), 617-635.

https://doi.org/10.5465/amj.2010.51468988

57. Rosin, H. \& Korabik, K. (1995). Organizational experiences and propensity to leave: A multivariate investigation of men and women managers. Journal of Vocational Behavior, 46(1), 1-16. https://doi.org/10.1006/jvbe.1995.1001

58. Saks, A. M. (2006). Antecedents and consequences of employee engagement. Journal of Managerial Psychology, 21(7), 600-619. https://doi.org/10.1108/02683940610690169

59. Schaufeli, W. B. (2013). What is engagement?. In Truss et al. (Eds.), Employee Engagement in Theory and Practice (pp.1-37). Routledge.

60. Schaufeli, W. B. \& Bakker, A. B. (2004). Job demands, job resources, and their relationship with burnout and engagement: a multi-sample study. Journal of Organizational Behavior, 25(3), 293-315.

https://doi.org/10.1002/job.248

61. Schaufeli, W. B., Salanova, M., González-Romá, V. \& Bakker, A. B. (2002). The measurement of engagement and burnout: A two sample confirmatory factor analytic approach. Journal of Happiness Studies, 3(1), 71-92. https://doi.org/10.1023/A:1015630930326

62. Shuck, B., Reio, T. G. \& Rocco, T. S. (2011). Employee engagement: An examination of antecedent and outcome variables. Human Resource Development International, 14(4), 427-445.

https://doi.org/10.1080/13678868.2011.601587

63. Singh, A. K. \& Singh, S. (2013). Perceived organisational support and organisational citizenship behaviour: The mediating role of personality. Journal of the Indian Academy of Applied Psychology, 39(1), 117-125.

64. Tanrı̈ver, Ü. (2005). The effects of learning organization climate and self-directed learning on job satisfaction, affective commitment and intention to turnover [Master's thesis, Marmara Üniversitesi]. Marmara Üniversitesi.

65. Tett, R. P. \& Meyer, J. P. (1993). Job satisfaction, organizational commitment, turnover intention and turnover: Path analyses based on meta-analytic findings. Personnel Psychology, 46(2), 259-293.

https://doi.org/10.1111/j.1744-6570.1993.tb00874.x

66. Thirapatsakun, T., Kuntonbutr, C. \& Mechinda P. (2014). The Relationships among Job Demands, Work Engagement, and Turnover Intentions in the Multiple Groups of Different Levels of Perceived Organizational Supports. Universal Journal of Management, 2(7), 272-285.

67. Wang, Q. \& Wang, C. (2020). Reducing turnover intention: perceived organizational support for frontline employees. Frontiers of Business Research in China, 14(6), 1-16. https://doi.org/10.1186/s11782-020-00074-6

68. Xanthopoulou, D., Bakker, A. B., Demerouti, E. \& Schaufeli, W. B. (2009). Reciprocal relationships between job resources, personal resources, and work engagement. Journal of Vocational Behavior, 74.(3), 235-244. https://doi.org/10.1016/j.jvb.2008.11.003 
69. Yakut, E. (2020). Örgütsel Destek Algısının İșten Ayrılma Niyeti Etkisinde Personel Güçlendirmenin Aracı ve Düzenleyici Rolü:Tekstil Sektöründe Yapısal Eşitlik Modeli Uygulaması. Uluslararası Toplum Araştırmaları Dergisi, 15(26), 4070-4100. https://doi.org/10.26466/opus.738785

70. Zacher, H. \& Winter, G. (2011). Eldercare demands, strain, and work engagement: The moderating role of perceived organizational support. Journal of Vocational Behavior, 79(3), 667-680. https://doi.org/10.1016/j.jvb.2011.03.020

71. Zhang, X., Bian, L., Bai, X., Kong, D., Liu, L., Chen, Q. \& Li, N. (2020). The influence of job satisfaction, resilience and work engagement on turnover intention among village doctors in China: A cross-sectional study. BMC Health Service Research, 20(283), 1-11. https://doi.org/10.1186/s12913-020-05154-0 